\title{
Analyses and Countermeasures of Current British-American Literature Course Teaching for English Major Students in China
}

\author{
WANG Hong-chang, XU Zhong-ming \\ Nanhu College of Jiaxing University, Jiaxing, China
}

\begin{abstract}
Tremendous data and materials indicate that British-American literature course, as the compulsive course for English major students, has been overlooked by the authority of various administrative departments and students as well. The majorities of teachers and students have formed the conception of attaching more importance to skill-gaining than literature-acquisition. Furthermore, there are large quantities of questionnaires and analyses conducted by the author in this essay; meanwhile, this essay offers some countermeasures to solve the current situation of British-American literature course.
\end{abstract}

Keywords: British-American literature, English major students, analyses, countermeasures

\section{Introduction and Lead-in}

It is universally acknowledged that British-American literature course is the most important ingredient for English major students; it has been stipulated as the compulsive course by the committee of English group as authority's approval, for the purpose of boosting students' language skills and promoting their humanistic qualities by reading and analyzing British and American literature works. ${ }^{1}$ Obviously, literature teaching is an indispensable form of molding college students' moral sentiment for quality-oriented education. What is more, literature teaching is the effective means of cultivating students' comprehensive qualities. But at present along with the execution of market-oriented economic policy, most English departments in some universities, in order to adjust to the reform and open policy and the requirement for various of talents in English, add some practical courses or compounded courses, ignoring British-American course as the basic course for English major students. Some teaching plans for English major over-weigh some practical courses, therefore, little weight is attached to British-American course. Some authorities and students place practical skill-gaining in the prior option. This phenomenon is manifested in the following aspects: (1) Teachers pay more attention to language teaching and some other practical course, overlooking the teaching of British-American course; (2) Students of English major have no utter understanding of the significance and role of British-American course, having no effective method of the acquisition of British-American course; (3) A large number of teachers have not master various teaching skills of British-American course, most of which are employing the traditional and stubborn stereotype; (4) There

WANG Hong-chang, lecturer, bachelor, Humanities Department, Nanhu College of Jiaxing University.

XU Zhong-ming, lecturer, bachelor, Humanities Department, Nanhu College of Jiaxing University.

1 English Group of College Foreign Language Teaching Steering Committee. (2000). Syllabus for English majors of colleges and universities. Shanghai: Shanghai Foreign Language Education Press. 
exists the great shortage of appropriate teaching materials for British-American course learners; and (5) There is the insufficiency for some teachers who focus on the research of British-American course in some universities, especially in some Natural Sciences and Technology Colleges, and the like. According to the survey, there are only $38 \%$ junior students and senior students in English major who are satisfied with the teaching of British-American course.

In the latest decades, this phenomenon is intriguing the attention by some researchers in the field of English. Some researchers expressed their worries about the current situation of British-American course. Supposing this kind of situation lasted long, it would lead to the unbalanced knowledge structure for English major students. Some researchers make it clear that literature and linguistic should be equally weighed in the courses-designing for English major, and they pointed out the significance and necessity of literature-requiring and research for English major students. For instance, appealing for "enhancing the teaching of British-American course" (Dai \& \& YU, 2000, p. 12); The makers of higher school professional English syllabus arrive at consensus that this phenomenon is a vulnerable point of English teaching in recent years (HE, 2001); Furthermore, most textbooks of British-American course are out-dated because woks and writers "belong to classic ones rather than the contemporary ones" (HE, 2001, p. 5). In summary, we should not be optimistic about the situation of British-American course teaching for English major students in the context of China's in-depth educational reform.

\begin{abstract}
About the Survey
Above all, I initiate the survey from the following perspectives: (1) purpose: gaining the detailed information of British-American course in some colleges and reflecting the current situation of it in China; offering some reliable data as reference for the reform of British-American course, etc.; (2) surveyee: 120 English major students enrolled in 2010 and 80 English major students enrolled in 2009 in way of conducting questionnaires. Meanwhile, four teachers who are engaged in British-American course teaching are included in the way of interview; (3) instrument: by the means of conducting questionnaires and interviewing interviewees. At the same time, analyzing the data by using software of SPSS (Statistical Package for the Social Sciences); and (4) process of the survey: above all, to deliver questionnaires to 120 English major students enrolled in British-American course and 80 English major students enrolled in 2009 respectively. The questionnaires cover the content of their preference between pure skill-gaining course and literature-acquisition course, their attitude to literature acquisition, their opinion on the significance of literature acquisition, their method of mastering this course, their resources of getting materials as extra-curriculum reading, and the like. Secondly, on the basis of the data from the information mentioned above, make up a quiz for them to testify whether they master the focal points and the degree of the focal points or not. In addition, interview four teachers who are engaged in British-American course teaching, concerning their teaching method, their teaching means (using conventional means or multiple-media as assisting tool or not at all), the frequency of using textbook, and their opinion on this course, etc.
\end{abstract}

\title{
Findings of the Survey
}

Generally speaking, the number of students that like or like British-American literature course very much is 
less than that of skill-gaining courses. Most students take it for granted that nowadays society needs a large quantity of the English talents who possess mastery of practical language skills. On the contrary, the majority of them reckon that learning British-American literature, especially learning those classic British-American literature works is of no use in reality. Therefore, A great number of the students have little enthusiasm in British-American literature. Many students think that there is a contradiction about the allocation of their spare time on British-American literature and some other practical courses; almost none of them spend time on preview and review the British-American literature and much fewer prepare some activities for this course. Meanwhile, about $72.3 \%$ of the students enrolled in 2010 and $54.4 \%$ of the students enrolled in 2009 have no clear awareness of the significance of British-American literature learning.

By interviewing five teachers who have been engaged in British-American literature teaching, the author finds out that there are not enough teachers who focus their attention on British-American literature teaching and research. For instance, most of them has no course-awareness at all. A large proportion of them have no materials or textbooks written by themselves. As for the means of teaching in classroom, about $93.4 \%$ of the teachers adopt the traditional method and tools, with no modern multi-media technology. It is a great pity that new methodologies of teaching related to this course are not employed yet. It is self-evident that there is a long way to go about the employment of modern teaching means in the teaching of British-American literature course. The process includes updating of new teaching concept, amount of money input into this course, necessary facilitation construction, and training of professional teachers as well.

\section{Analyses}

In some degree, British-American literature course refers to the combination of curricula including selective reading of British-American play, selective reading of British-American novels, British-American literature history, selective reading of British-American poetry, etc. Curriculum awareness means that teachers take some materials written by themselves out of inspiration as partial ingredient of the whole course, instead of regarding the ready-made textbooks as the whole content of the course. In addition, teachers of the course have the right to delete or augment some materials to organize the teaching activities according to the actual situations. It is pointed out that curriculum is organized with the media of textbook as well as open, democratic, and scientific activities (Zhu, 1992, p. 72). Therefore, it is urgent for teachers who have been engaged in British-American literature teaching to update their teaching method related to this course.

As far as English major students are concerned, they should enhance the knowledge of English major, and overturn their superficial opinion on British-American literature course; especially, they should change the thought of being anxious to achieve quick success and getting instant benefits from it. Most importantly, English major students should master some effective methods of British-American literature acquisition.

\section{Countermeasures and Conclusion}

(1) Adapting to the arrival of hypertextualization: Try all means to take advantages of audio-visual multimedia teaching method. Ted Nelson coined the word hypertext in 1965, and at that time this word was used to refer to nonlinear information management technology. Later on, the Newcomer Award established by international hypertextualization was assembly named after its name. Actually, hypertextualization is an overall 
technology structure. And its constitutive ingredient includes nodes, linkage, and network as well. In detail, network is an enormous hypertext written by Hypertext Markup Language; furthermore, the communication context on the basis of network is actually hypertextualizational context. Hypertext covers various reading means of human being ranging from closed and static linear system to open and dynamic network. The theorist of hypertext Landow once pointed out that there are a few common characteristics between hypertextualization and some other critical theories. ${ }^{2}$ According to this concept and the connotation, we found out that the traditional dull teacher-centered teaching method is against the tide of diversity in hypertextualizational context, and this ultimately leads to the bilateral vicious circle. On the one hand, teachers have no creative idea about teaching, on the other hand, students are getting fed up with this course.

Paper-based traditional textualized literature teaching has much more limitation than hypertextualizational form, such as audio-visual multimedia teaching, bulletin board system, web log, etc. Paper-based traditional textualized literature has been compared as frozen speech, therefore, we should substitute the dull teacher-centered reading and paraphrasing textualized British and American literature teaching method with vivid multi-media technologies gradually. For instance, when teaching the classic masterpiece Pride and Prejudice by Jane Austen, almost all of us are clear about the content that it describes the love story as well as the illustration of the society in Britain in the 18th century, the different statuses of marriage between Charlotte Lucas and Mr. Collins together with the marriage between Darcy and Elizabeth. Supposing students are offered to watch the movie form which is adopted according the masterpiece, there would be the vivid visual sceneries for students to appreciate, and they would be deeply impressed by the fantastic gardens and landscapes. At the same time, through the audio form students can gain various colloquial speeches and cross-cultural ideas as well. All the aspects mentioned above are beneficial to them to enhance the understanding of the masterpiece.

In addition, Computer-Assisted Language Learning is playing a more and more important role nowadays. According to the "Syllabus", modern and versatile teaching methods should be employed in the teaching process, we should attach increasing importance to the vital role played in the field of renovating teaching content, altering acquiring pattern, and promoting learning efficiency by computer and network. It is worthwhile to notice that English teaching conception was summarized as to be individualized, hypertextualized, cooperated, and patterned forms by College English Curriculum Requirements in 2007. ${ }^{3}$ Therefore, the innovation on college English teaching method from textual form to hypertextual form can exert far-reaching impact on and beneficial significance for British-American literature teaching (Huo, 2006, p. 10).

Most importantly, teachers shoulder the responsibility of making it clear for students to take full advantages of advanced Computer-Aided Language Learning theory, both parts including students and teachers should transfer conceptual idea into practical actions. Take the innovative pedagogical method of Podcastingfor instance, the New Oxford American Dictionary announced "podcast" the word in the year of 2005. Podcasting is an "innovative, asynchronous communication tool” (Jalali, Leddy, Gauthier, Sun, Hincke, \& Carnegie, 2008, p. 193). Therefore, Podcasting is the superior form of blog comparatively, characterizing by sounds and images. By utilizing this method in the acquisition of British-American literature, students' motivation can be fully triggered.

\footnotetext{
${ }^{2}$ HUO, H. Y. (2006). Hypertext context and literature teaching. Journal of Language and Literature Studies.

3 Department of Higher Education in the Ministry of Education. (2007). College English curriculum requirements. Beijing: Foreign Language Teaching and Research Press.
} 
(2) To attach more importance to literature criticism and literature theory and assist their analyzing ability: As a matter of fact, literature criticism and literature theory are indispensable to literature course itself; they can direct learners' appreciation skills and analysis qualities throughout British-American literature course from various aspects. Literature criticism and literature theory can be employed to reveal some characteristics and essence in enlightening learners' unique opinion.

Take the study of the masterpiece Pride and Prejudice as an example. The initial sentence in this masterpiece is impressive. It reads: "It is a truth universally acknowledged, that a single man in possession of a good fortune, must be in want of a wife". ${ }^{4}$ The implication is very obvious that the foundation of the marriage at that time is not love but possession. As far as I am concerned, Pride and Prejudice reflects the British sentiment of the end of 18th century and the early of 19th century under the circumstance of conservative, and it tells us different ways and attitudes towards marriage between Mr. and Mrs. Bennet's five daughters. In some degree this novel reveals the authoress' attitude toward marriage. In the authoress' opinion, it is wrong to get married for property, money, and position. It is unwise to get married without considering the above-mentioned elements. Besides, the authoress objects to getting married for money, objects to regarding marriage as a trifling matter. She emphasizes the importance of the ideal marriage between Darcy and Elizabeth, and regards men and women's affection as the foundation stone which constitutes the ideal marriage. First of all, if we take a Feminist Approach to this masterpiece, we ought to be familiar with Austen's background: She was born in a mid-class family and unmarried all her life. She was brought up in a comfortable environment with harmonious surroundings. In Pride and Prejudice she talked different ideas and opinions on love and marriage through different characters. Jane Austen disclosed mid-class young ladies' different ideas of marriage and love through describing the different ways in which the Bennet girls do with their marriage problems, and this undoubtedly indicates the writer's opinion on love and marriage: in a word, it is wrong to get married just for property, wealth, and status while neither would it be without caring about those elements. Jane Austen just attached great significance to marriage through her novel by telling people that marriage should be regarded carefully for it is not a game you can just enjoy without prudent consideration. She also wants to deliver information that marriage should be based on real affection between the lovers. The female heroine Elizabeth is a mid-class girl. Darcy proposed to her regardless of the gap between them, but Elizabeth refused because his pride had formed Elizabeth's prejudice. But later Darcy's doings especially his change of the prideful manner eliminated Elizabeth's misunderstandings and prejudice against him, and Elizabeth accepted his proposal. Those two opposite attitudes reflect female's pursuit of independent personality and equality. I think Elizabeth has personality ethic which caused her independent idea about love and marriage and in consequence she gained a happy life. There are also Elizabeth's sisters' love stories served as contrasts to Jane Austen's Feminist ideal marriage. Feminism is a term which involves various movements, ideas, theories, and philosophies which are concerned with the issue of gender difference. It advocates equality for women and campaigns for women's rights and interests. The exploring theme of feminism includes discrimination, stereotyped image, materialization of sex, oppression, and paternity. In this masterpiece, the authoress showed her philosophy and idea on the issue of gender equality, especially her scorn on male's materialization of sex. According to western history, in the early 19th century, the majority of the women in

${ }^{4}$ Landow, G. P. (1994). What's a critic to do? Critical theory in the age of hypertext. Landon Baltimore: Johns Hopkins University Press. 
western countries have not gained equal human rights and most women were living in the whole male-dominated society. In social life and people's sense, women were still in an inferior position. So feminists began to realize that there still existed a problem of gender inequality. Therefore, feminism theory turned into the analysis of the origin of inequality between men and women. It became a kind of belief and ideology aiming at eliminating all inequality including sexual discrimination. Secondly, from the perspective of eco-literature, the authoress' splendid description of the manor in Hertfordshire implied her metaphor of the harmony between nature and human. Eco-literature is founded on the basis of the whole ecology, and it regards the whole ecological benefit as "the utmost value for human beings" (WANG, 2011, p. 29). The authoress' description of the fantastic landscapes and wonderful scenery are the high praise for nature, so Jane Austen's concern is of great significance to human's wholeness, stability, and sustainability as well.

To summarize, it is so beneficial for English major students to master some main literature theories and criticism in analyzing and appreciating literature works.

\section{References}

CHEN, J. (1984). Selected reading in English literature. Beijing: Commercial Press.

CHEN, S. (2008). An investigation on the teaching effect of English and American literature by means of podcasting. Journal of Hubei University of Economics (Humanities and Social Science), 5(11), 193-195.

DAI, W. D., \& YU, J. H. (2000). English and American literary studies. Shanghai: Shanghai Foreign Language Education Press.

Department of Higher Education in the Ministry of Education. (2007). College English curriculum requirements. Beijing: Foreign Language Teaching and Research Press.

English Group of College Foreign Language Teaching Steering Committee. (2000). Syllabus for English majors of colleges and universities. Shanghai: Shanghai Foreign Language Education Press.

Harding, D. W. (2005). Regulated hatred: An aspect of the work of Jane Austen. In Jane Austen: A collection of critical essays (pp. 166-179). Oxford: Pergamon Press.

HE, Q. X. (2001). Fostering foreign language professionals in the 21 century-new "Syllabus" and the main features of the revision process. Foreign Language Circles, 81(1), 5.

HUO, H. Y. (2006). Hypertext context and literature teaching. Journal of Language and Literature Studies, 6(10), 31.

Jalali, A., Leddy, J., Gauthier, M., Sun, R., Hincke, M., \& Carnegie, J. (2011). Use of podcasting as an innovative asynchronous E-learning tool for student. US-China Education Review, 6(74), 71-74.

Landow, G. P. (1994). What's a critic to do? Critical theory in the age of hypertext. Landon Baltimore: Johns Hopkins University Press.

Locke, L. G. (1962). Introduction to literature. New York: New York Press.

LU, G. S. (1999). Three random thoughts on English teaching. Foreign Language and Foreign Language Teaching, $10(7), 27$.

WANG, N. (2011). Ecological literature in the Occident. Beijing: Beijing University Publishing House.

WANG, S. R., \& ZHAO, W. S. (2003). British literature teaching in the context of network environment. Foreign Language Teaching Abroad, 4(1), 25-28.

WANG, Z. L. (1981). An anthology of English literature. Beijing: Commercial Press.

YANG, K. S. (1984). Selected readings in English literature. Shanghai: Shanghai Translation Publishing House.

ZHU, X. M. (1992). The shake of new intelligence structure and western intellectualism education framework by H. Gadenna. Research on Higher Normal Education, 21(3), 72. 